\title{
Arginine in poultry nutrition
}

\section{2.* Chick arginase}

\author{
By G. H. SMITH AND D. LEWIS \\ University of Nottingham School of Agriculture, Sutton Bonington, \\ Loughborough
}

\section{(Received i8 October 1962-Revised 25 March 1963)}

It is recognized that the chick, in contrast to mammals, is unable to synthesize arginine (Klose, Stokstad \& Almquist, 1938), probably because birds lack certain enzymes of the urea cycle (see Cohen \& Brown, 1960). The function of this system in the excretion of waste nitrogenous products is taken over by the group of enzymes concerned in uric acid synthesis. Although the urea cycle as a whole is not operative in the chick, there is evidence that certain of its constituent enzymes are present (Cohen \& Brown, 1960). It is conceivable that the distribution and activity of these enzymes might influence the apparent requirement of the domestic chicken for dietary arginine.

Ingested arginine can follow several routes, but the mechanisms have been established only in some species. The three most prominent pathways are those involving protein synthesis, the formation of ornithine and urea under the action of the enzyme arginase and the production of guanidoacetic acid in the presence of glycine and the enzyme glycine transamidinase (Fig. 1). Since arginase appears to serve no essential function in the chick, and since a high liver arginase activity would waste arginine absorbed through the hepatic portal system, it appeared desirable to examine the arginase activity of chick liver and kidney. It was also thought necessary to determine whether the characteristics of the enzyme are similar to those of the arginase of mammalian species, and whether the activity varied with strain, age or diet.

Arginase is a highly specific enzyme and is generally considered only to catalyse the hydrolysis of $\mathrm{L}$-arginine into ornithine and urea. It does, however, attack a few derivatives with a substituent in the $\alpha$-amino group, such as octopine (arginine- $N$ - $\alpha$ propionic acid) and its isomers (Akashi, 1937). Information upon the occurrence of arginase in chicks is, however, scanty and that available needs to be confirmed since the methods used in the past cannot now be regarded as appropriate. Clementi (1915) stated that arginase was not found in avian liver and in fact concluded that the enzyme occurs in the liver of ureotelic animals only. On the other hand, Edlbacher \& Rothler $(1925 a, b)$ and Chaudhuri (1927-8) claimed that avian liver has a low arginase activity. There is little doubt, however, that avian kidney possesses the enzyme arginase, and there is some information available on its activity (Baldwin, 1935). Avian arginase

- Paper no. I: Brit. F. Nutr. (1963) I7, 415 . 
has not been examined in the light of recent knowledge of its properties, particularly with regard to the effects of cofactor concentration.

An assay of arginase activity by measurement of the disappearance of arginine from the reaction mixture is unsuitable for several reasons. The substrate concentration must be allowed to decrease by a measurable amount involving an inevitable departure from initial velocity conditions. Further, such a technique would be affected by other

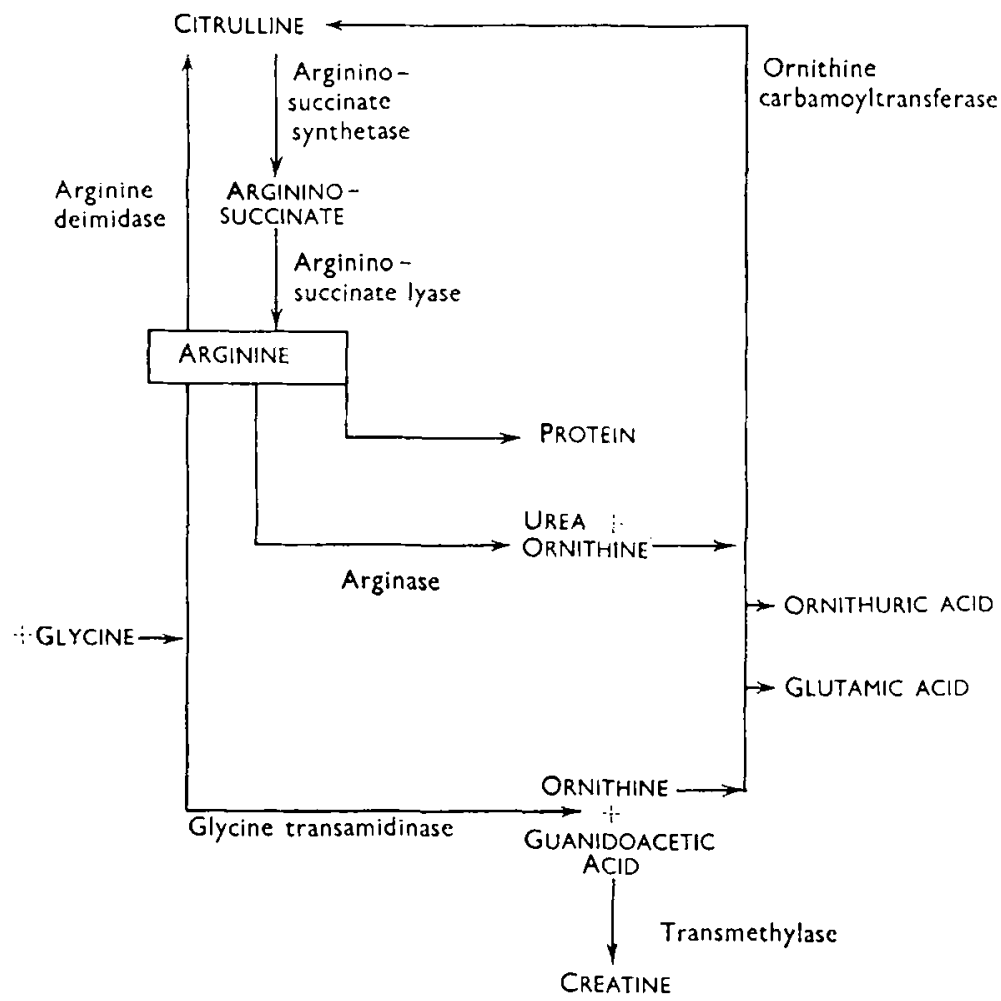

Fig. 1. Schematic representation of arginine metabolism.

enzymes which may attack arginine, such as transamidinases, transaminases and oxidases (Fig. I). The inhibitory action of ornithine upon arginase (Gross, 1920) also complicates the interpretation of the results.

It is more appropriate to follow the course of arginase action by measuring the rate of urea production. The usual techniques of urea determination employing a urease preparation proved to be unsatisfactory: it was not found possible to halt the arginase reaction in such a way that conditions remained appropriate for urease action. A colorimetric method for determining urea, whereby the colour produced by $\alpha$-isonitrosopropiophenone in acid solution is measured, has been described (Van Slyke \& Archibald, 1946) and this procedure has been adopted. 


\section{EXPERIMENTAL AND RESULTS}

\section{Arginase assay}

Birds were killed by dislocation of the neck and were bled. The kidneys and liver were removed immediately. Since it was generally inconvenient to assay the activity of a large number of samples immediately, they were all stored for a standard period of 3-4 days at $-15^{\circ}$ to ensure uniformity, care being taken to avoid desiccation.

Samples of tissue were homogenized in an all-glass Potter \& Elvehjem (1936) homogenizer cooled in ice. The homogenizing medium was a buffered solution containing manganous ions prepared according to the recipe of Greenberg ( $195 \mathrm{I}$ ): $5.8 \mathrm{~g}$ maleic acid were dissolved in $400 \mathrm{ml}$ water and the $\mathrm{pH}$ was adjusted to $9 \cdot 7-9.8$ with $\mathrm{N}-\mathrm{NaOH}$. This solution was added to $25 \mathrm{ml} 2 \mathrm{M}-\mathrm{MnSO}_{4}$ and the whole made up to $\mathrm{I}$. The final $\mathrm{pH}$ was approximately 7 and the solution equivalent to $0.05 \mathrm{M}$. More dilute buffers were prepared from this by dilution (which slightly raises the $\mathrm{pH}$ ) and addition of sufficient of a maleic acid-manganous sulphate solution of the required molarity to readjust the $\mathrm{pH}$ to $7 \cdot 0$. For use as a homogenizing medium the solution was diluted in this way to $0.00 \mathrm{I} \mathrm{M}$ and adjusted to $\mathrm{pH} 7.0$.

A $6 \mathrm{ml}$ volume of the homogenizing medium was added to a I $\mathrm{g}$ (wet weight) sample of tissue in the homogenizer and the pestle rotated at $2000 \mathrm{rev} / \mathrm{min}$ for from 0.5 to $\mathrm{I}$ min. The contents of the tube were transferred to a measuring cylinder and made up to $10 \mathrm{ml}$. The following standard homogenate concentrations were used for the assay: for rat kidney and chick liver and kidney preparations 20 and $10 \mathrm{mg} / \mathrm{ml}$; for rat liver I and $0.5 \mathrm{mg} / \mathrm{ml}$. The homogenates were pre-incubated at $37^{\circ}$ for a period of $60-80 \mathrm{~min}$ before assay, i.e. before any addition of substrate. This procedure ensured a standard equilibration with cofactor.

A substrate solution was prepared containing $0.425 \mathrm{M}$ L-arginine monohydrochloride adjusted to $\mathrm{pH} 9.5$ with $\mathrm{N}-\mathrm{NaOH}$. A volume of $1 \mathrm{ml}$ of this solution was placed in a centrifuge tube for each assay and brought to $37^{\circ}$ in a water-bath. To it was added $0.5 \mathrm{ml}$ of the pre-incubated homogenate (blown in sharply). A reaction time of 2 min was chosen for all samples except for chick liver, for which a period of $10 \mathrm{~min}$ was allowed. At the end of the incubation period, carefully timed, I $\mathrm{ml}$ of $15 \%(\mathrm{w} / \mathrm{v})$ $\mathrm{HPO}_{3}$ was added to halt the reaction. After standing for $15 \mathrm{~min}$ to allow uniform protein precipitation, the tubes were centrifuged and $2 \mathrm{ml}$ of the supernatant fluid were used for the determination of urea. Provided the $\mathrm{HPO}_{3}$ solution was freshly prepared, the supernatant liquid was clear and the filtration step recommended by Van Slyke \& Archibald (1946) unnecessary. The coloured product with $\alpha$-isonitrosopropiophenone was determined in an EEL (Evans Electroselenium Ltd, Essex) colorimeter with an Ilford filter no. 625 by the procedure described by Van Slyke \& Archibald (1946).

\section{Properties of chick arginase}

The kidneys of White Leghorn $\times$ Light Sussex cockerels, 6-10 weeks old, were used. A standard temperature of $37^{\circ}$ was selected for the reaction as it enabled comparison to be made with the mammalian system. No evidence has been found to suggest that chick arginase is unstable at this temperature during incubation. 
Effect of cofactors. Mammalian arginase is activated by divalent metal ions, especially $\mathrm{Mn}^{2+}, \mathrm{Ni}^{2+}$ and $\mathrm{Co}^{2+}$ (Greenberg, $\left.195 \mathrm{I}\right)$. It is believed that a reaction takes place between the metal and an inactive pro-arginase to yield a complex which is the active form. Arginase is activated in vivo by metal ions in the tissue and on dilution during homogenization these ions will dissociate from it, leading to a reduction in activity. Chick arginase was therefore examined to see whether it behaved in the same way. A homogenate of chick kidney was prepared with distilled water as the medium so that it contained the equivalent of $45 \mathrm{mg}$ original tissue $/ \mathrm{ml}$. This preparation was

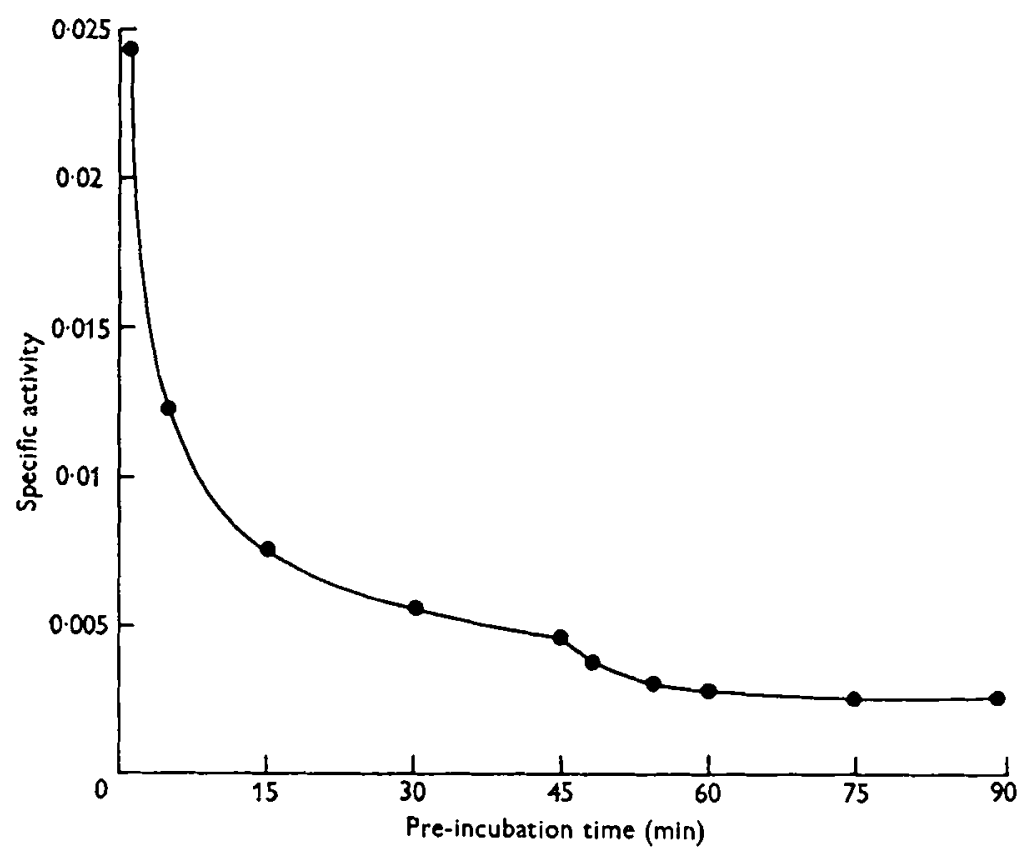

Fig. 2. Activity of arginase in homogenate of chick kidney prepared with water and held at $37^{\circ}$ before incubation with substrate. The specific activity is expressed as $\mu$ moles urea produced/min $\mathrm{mg}$ tissue. Experimental details are given on p. 435 .

incubated at $37^{\circ}$, and at intervals after homogenization the activity of $0.5 \mathrm{ml}$ samples was determined by the standard method. After $45 \mathrm{~min}$ the homogenate was further diluted with an equal volume of distilled water and samples were again taken at intervals. The results shown in Fig. 2 demonstrate the apparent decrease in enzyme activity that occurred under these circumstances. This decrease was presumably due to the dissociation of divalent ions from the active arginase: the effect of a second dilution with distilled water was to lead to a further decrease in specific activity as another equilibrium condition was approached.

Since kidney tissue is likely to contain different levels of activating ions and since the process of preparing the homogenate may not uniformly allow dissociation of the active enzyme complex to proceed, it has been considered necessary to incorporate $\mathrm{Mn}^{2+}$ ions in the homogenizing medium. Moreover, activation of arginase by $\mathrm{Mn}^{2+}$ ions is a comparatively slow reaction and it is therefore necessary to incubate the homo- 
genate in the presence of $\mathrm{Mn}^{2+}$ ions to allow equilibration before use. Several experiments were carried out to determine the optimum time of pre-incubation and it was generally found that there was an increase in activity as the time of incubation increased. Different samples of tissue varied somewhat in this respect and it was found necessary to select arbitrary conditions for pre-incubation. Within the range of $\mathrm{Mn}^{2+}$ ion and homogenate concentrations tested, however, it was found that after $60 \mathrm{~min}$ incubation equilibrium was approached and change of activity after this interval was slight. The effect of incubation with different concentrations of $\mathrm{Mn}^{2+}$ ions is illustrated

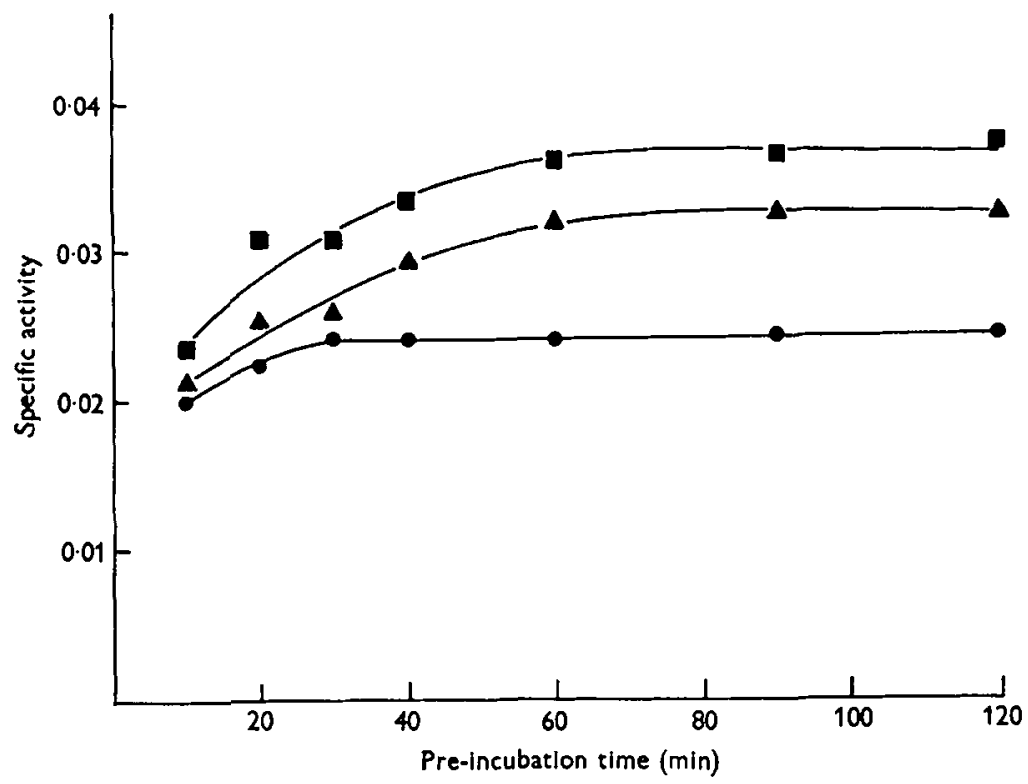

Fig. 3. Effect of incubation with different concentrations of $\mathrm{Mn}^{2+}$ ions upon the arginase activity of a homogenate of chick kidney. A homogenate was prepared in $0.00 \mathrm{r} \mathrm{M}-\mathrm{Mn}^{2+}$-maleate buffer in the standard manner described in the text, and samples were diluted with $\mathrm{Mn}^{2+}-$ maleate buffer of different concentrations so as to produce three mixtures, each containing $15 \mathrm{mg}$ original tissue $/ \mathrm{ml}$ and $\mathrm{Mn}^{2+}$ concentrations of $0.009 \mathrm{M}, 0.005 \mathrm{M}$ and $0.00 \mathrm{I} \mathrm{M}$. These were incubated at $37^{\circ}$. The results are plotted as specific activity (see Fig. 2) against the time of incubation: $\mathrm{m}, \mathrm{Mn}^{2+}$ concentration $0.009 \mathrm{M} ; \mathrm{A}, 0.005 \mathrm{M} ; \bullet, 0.00 \mathrm{I} \mathrm{M}$.

by the results shown in Fig. 3. Activity was increased by the use of greater cofactor concentrations but always an equilibrium was attained after $60 \mathrm{~min}$, and thereafter there was little change in activity.

The selection of the appropriate concentrations of activating ion is not determined solely by the level which gives maximum activation. Excess $\mathrm{Mn}^{2+}$ ions produce undesirable effects particularly when the more dilute homogenates are used. It was found that when a $0.01 \mathrm{M}-\mathrm{MnSO}_{4}$-maleate solution was used as the homogenizing and diluting medium there was a decrease in the specific activity of arginase with increasing dilution. This observation is also illustrated by an experiment in which the course of urea production in the presence of different quantities of homogenate was examined. The homogenate $(15 \mathrm{mg} / \mathrm{ml})$ was prepared with $0.01 \mathrm{M}-\mathrm{MnSO}_{4}$-maleate buffer and three samples of it were incubated with different amounts of 0.425 
$\mathrm{M}$-arginine hydrochloride and buffer solution so that, whereas the final substrate concentration was always $0.285 \mathrm{M}$ and the $\mathrm{Mn}^{2+}$ ion concentration was equivalent to $0.0033 \mathrm{M}$, the homogenate concentrations in the three mixtures were 5,2 and $0.5 \mathrm{mg}$ tissue/ml respectively. As shown in Fig. 4, there was always a linear production of urea for 10 min but there was a decrease in the specific activity of the enzyme with increasing dilution, i.e. $0.065,0.060$ and $0.040 \mu \mathrm{mole}$ urea/min $\mathrm{mg}$ tissue in the three mixtures respectively. It is likely that this decrease in specific activity of the enzyme is associated with the effects of dilution and cofactor concentration. A range of $\mathrm{Mn}^{2+}$ ions was tested and it was found that the use of a $0.00 \mathrm{I} \mathrm{M}-\mathrm{MnSO}_{4}$-maleate buffer

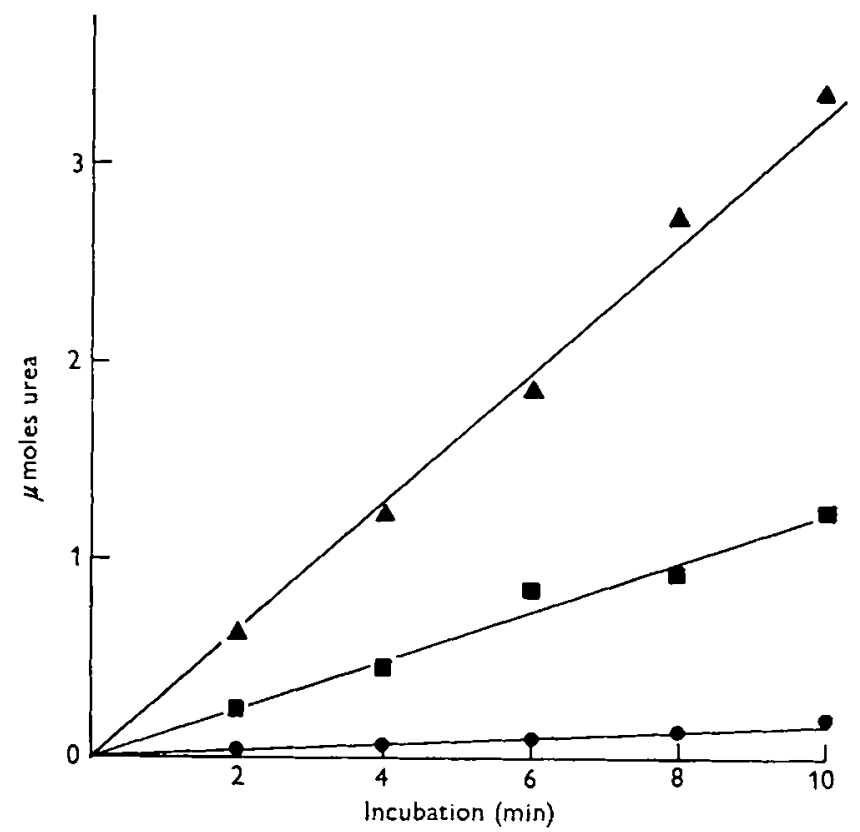

Fig. 4. Course of urea production in the presence of different concentrations of homogenate of chick kidncy. Experimental details are given on p. 437; activity is expressed as $\mu$ moles urea produced $/ \mathrm{ml}$ reaction mixture.,$- 5 \mathrm{mg}$ homogenate $/ \mathrm{ml} ; \Delta, 2 \mathrm{mg} / \mathrm{ml} ; \bullet, 0.5 \mathrm{mg} / \mathrm{ml}$.

solution produced the most desirable compromise between the need to avoid this effect and the necessity to activate the enzyme. Provided that dilution was made before pre-incubation, the effect upon the linearity of activity in relation to homogenate concentrations was slight. The results shown in Fig. 5 illustrate the linearity achieved under the standard conditions described for arginase assay.

Optimum $\mathrm{pH}$. To examine the effects of hydrogen ion concentration upon arginase activity a homogenate was prepared and pre-incubated in $0.00 \mathrm{I} \mathrm{M}-\mathrm{MnSO}_{4}$-maleate buffer in the standard manner: the concentration was equivalent to $25 \mathrm{mg}$ tissue $/ \mathrm{ml}$. Centrifuge tubes were prepared, each to contain $\mathrm{I} \mathrm{ml}$ of a $0.015 \mathrm{M}$-solution of arginine, buffered to a range of $\mathrm{pH}$ values. It was found necessary to use a more dilute solution of substrate because of the difficulties of $\mathrm{pH}$ adjustment duc to the buffering capacity of arginine. There was no reason to believe that at the lower substrate concentrations 
initial-velocity conditions were not achieved. The final buffer concentration in the reaction mixture was equivalent to $0.066 \mathrm{M}$, glycine- $\mathrm{NaOH}$ being used within the $\mathrm{pH}$ range 8.5-I I.5 and $\mathrm{Na}_{2} \mathrm{HPO}_{4}-\mathrm{KH}_{2} \mathrm{PO}_{4}$ at $\mathrm{pH} 6-8 \cdot 5$. The $\mathrm{pH}$ in the final mixture was determined with a Pye Master pH Meter (W. G. Pye and Co. Ltd, Cambridge). To each centrifuge tube was added $0.5 \mathrm{ml}$ of the homogenate.

The optimum $\mathrm{pH}$ of chick arginase determined under these conditions was around 10.0 (Fig. 6). However, in view of the rapid fall in activity at $\mathrm{pH}$ values above ro, probably caused by enzyme instability, and the difficulty of maintaining and measuring the $\mathrm{pH}$ of buffers in this region, a $\mathrm{pH}$ of 9.5 was used in the standard assay.

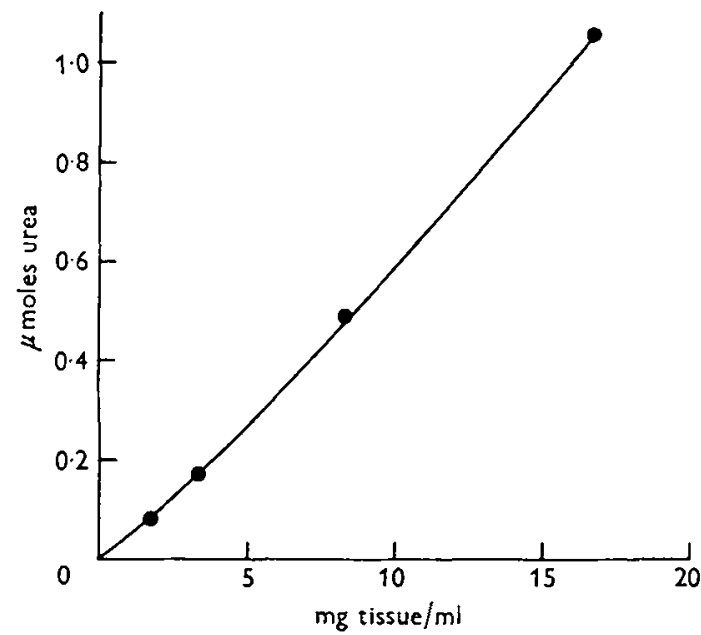

Fig. 5. Arginase activity of homogenate of chick kidney plotted against the concentration of original tissue in the reaction mixture. A homogenate was prepared with $0.001 \mathrm{M}-\mathrm{Mn}^{2+}-$ maleate buffer in the standard manner and samples were diluted with $0.00 \mathrm{I} \mathrm{M}-\mathrm{Mn}^{2+}-$ maleate $^{2}$ buffer to produce four different concentrations of homogenate. These were incubated at $37^{\circ}$ for 60 min before assay for activity by the standard method. Activity is expressed as $\mu$ moles urea produced $/ \mathrm{min} \mathrm{ml}$ reaction mixture.

Effect of substrate concentration. An experiment was carried out to determine the affinity of chick arginase for arginine. A kidney homogenate was prepared in the standard manner, diluted to $15 \mathrm{mg}$ tissue/ml and pre-incubated at $37^{\circ}$ for $\mathrm{I}$ h before use. Solutions of L-arginine monohydrochloride and glycine (buffer) were adjusted to $\mathrm{pH} 9 \cdot 5$ with $\mathrm{NaOH}$ and to a concentration of $\mathrm{O} \cdot \mathrm{I} \mathrm{M}$. Centrifuge tubes were prepared, each containing $3 \mathrm{ml}$ of a mixture of these solutions to give a series of six arginine concentrations. Three tubes were prepared for each concentration of arginine. They were brought to $37^{\circ}$ in a water-bath and $\mathrm{I} \mathrm{ml}$ of homogenate was added sharply. The reaction was allowed to proceed and urea concentrations were determined in the standard manner. Since the supernatant fluids used for urea determination finally contained varying amounts of arginine it was necessary to allow for the effect upon the colour reaction. This end was accomplished by preparing a series of urea standards also containing a range of arginine concentrations. The colour developed in them was plotted against the arginine concentrations, and from this graph a correction was derived for each experimental determination. The results, so corrected, are given in 


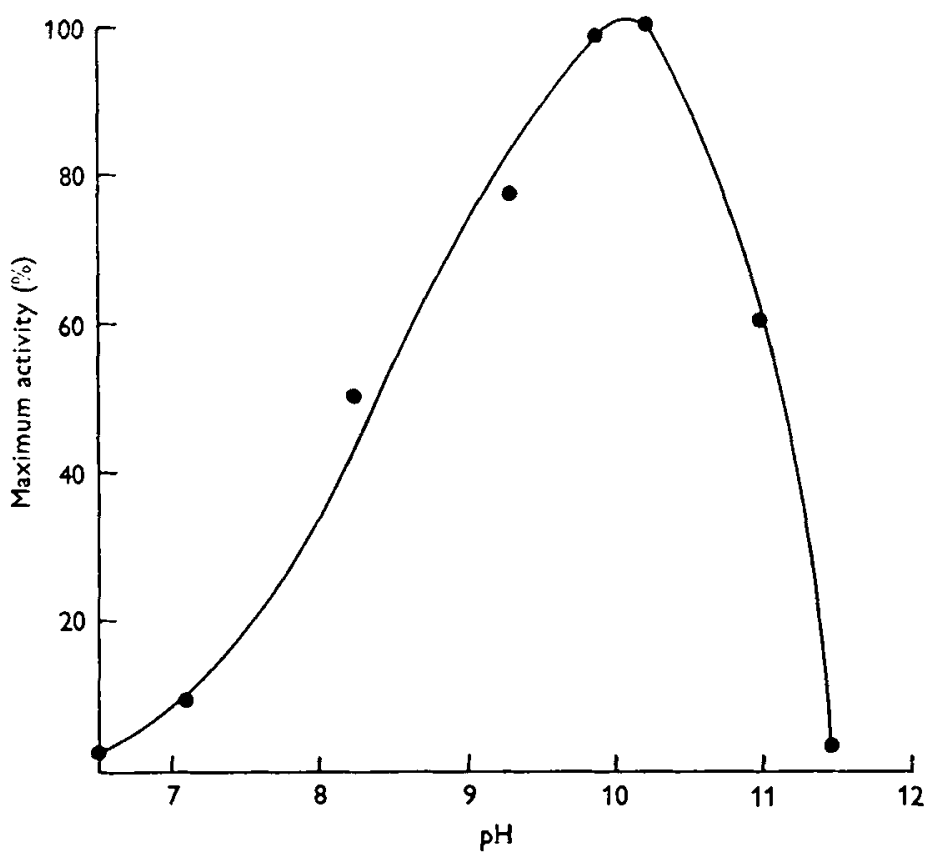

Fig. 6. Effect of $\mathrm{pH}$ in the reaction mixture upon the rate of urea production from arginine by a homogenate of chick kidney. Experimental details are given on p. 438 . The results are plotted as percentage maximum activity against the $\mathrm{pH}$ of the reaction mixture. Each point is the mean for two assays.

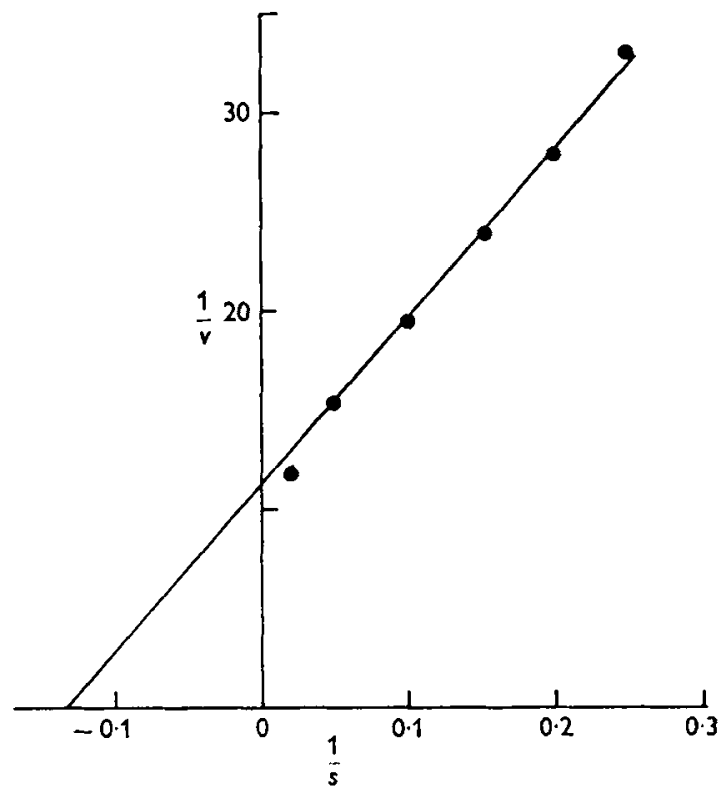

Fig. 7. Effect of substrate concentration upon arginase activity of chick kidney homogenate. Experimental details are given on p. 439. The velocity $(v)$ of the reaction is expressed as $\mu$ moles urea produced $/ \mathrm{min} \mathrm{ml}$ tissue. The reciprocal $(\mathrm{r} / \mathrm{v})$ of these values is plotted against the reciprocal $(\mathrm{r} / \mathrm{s})$ of the arginine concentration in the reaction mixture $(\mathrm{mM})$. 
Fig. 7 in the form of a Lineweaver \& Burk (1934) plot. A $K_{m}$ value of $7.7 \times 10^{-3} \mathrm{M}$ was obtained from this experiment.

Conditions of assay. A standard temperature of $37^{\circ}$ was selected for the reaction. The cofactor concentration and period of pre-incubation were determined in the light of the results that have been given. The reaction was carried out at $\mathrm{pH} 9 \cdot 5$ for the reasons already stated. Owing to the relatively low substrate affinity of the enzyme and the possibility that the ornithine produced in the reaction may cause a departure from initial-velocity conditions through competitive inhibition, the high substrate

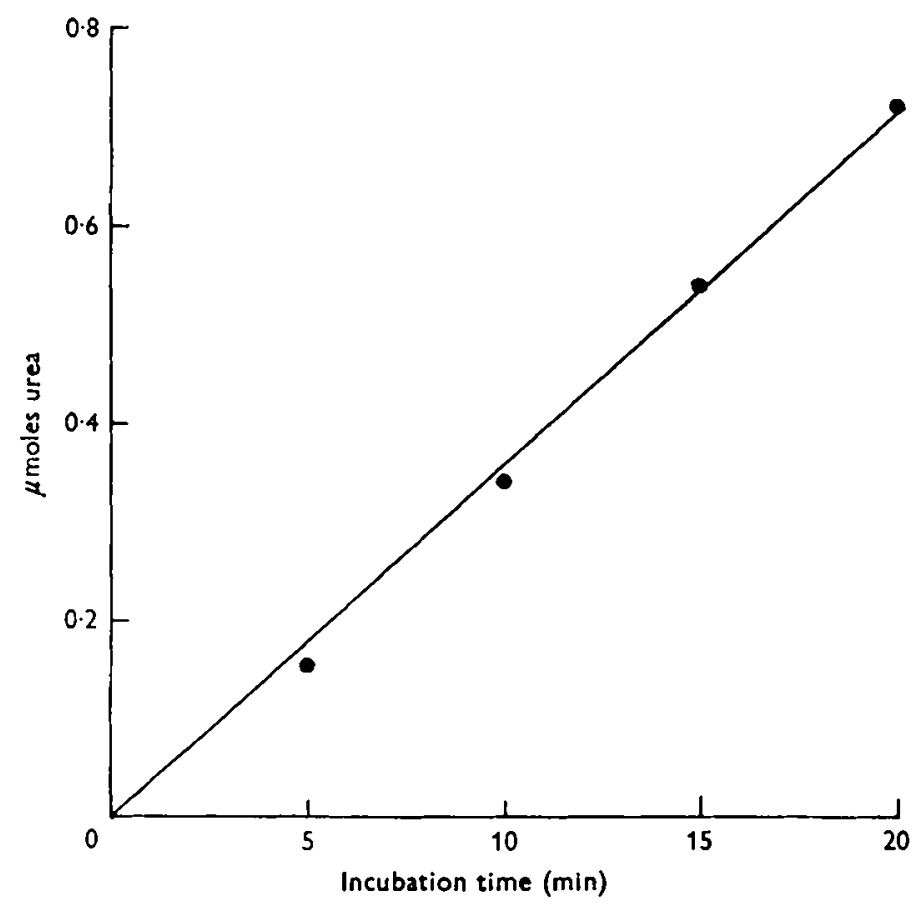

Fig. 8. Course of urea production from arginine by a homogenate of chick liver. Experimental details are given on this page. The urea production is expressed in $\mu$ moles $/ \mathrm{ml} \mathrm{reaction} \mathrm{mixture.}$

concentration recommended by Van Slyke \& Archibald (1946) was adopted. Arginine itself acts as a buffer (with $\mathrm{NaOH}$ ) at this $\mathrm{pH}$. That urea production is linear for 10 min under these conditions is evident from Fig. 4.

Since the properties of the renal arginase resemble those of the mammalian enzyme (see below) this method is also suitable for investigating the activity of chick liver. Since this organ possesses less arginase activity per unit weight than does kidney it is necessary to allow longer reaction times if similar homogenate concentrations are used. The results of an experiment to examine whether initial-velocity conditions were maintained over longer periods when liver material was used are shown in Fig. 8. A homogenate of chick liver was prepared by the standard method, diluted to a concentration equivalent to $15 \mathrm{mg}$ tissue $/ \mathrm{ml}$ and pre-incubated for $60 \mathrm{~min}$ at $37^{\circ}$. 


\section{Arginase activity of chick liver and kidney}

The liver and kidneys were removed from fifteen ro-week old White Leghorn chicks and stored at $-14^{\circ}$. The arginase activities of these organs were determined by the standard method. To allow comparison of these results with those obtained in the same way for a mammal, the livers and kidneys of fourteen white rats were also removed and the arginase activity was assayed in the same way. The results are summarized in Table I, which shows that the arginase activity of chick liver, though low, is significant.

'Table 1. Arginase activity of liver and kidney preparations from rat and chick, expressed as jumoles urea produced/h $g$ wet weight of tissue

$\begin{array}{lcccc}\quad \text { Material } & \begin{array}{c}\text { No. of } \\ \text { animals }\end{array} & \begin{array}{c}\text { Mcan } \\ \text { activity }\end{array} & \begin{array}{c}\text { Standard error } \\ \text { of mean }\end{array} & \begin{array}{c}\text { Coefficient of } \\ \text { variation }(\%)\end{array} \\ \text { Rat liver } & 14 & 117000 & \pm 3200 & 10 \\ \text { Rat kidney } & 14 & 2250 & \pm 130 & 22 \\ \text { Chick liver } & 15 & 380 & \pm 98 & 50 \\ \text { Chick kidney } & 15 & 4000 & \pm 103 & 58\end{array}$

Table 2. Kidney arginase activity, expressed as $\mu$ moles urea produced/h $\mathrm{g}$ wet weight tissue, in relation to age and diet of chicks

(Each figure is the mean of four determinations. Diet $A$ contained $\times 2 \%$ arginine and diet $130.8 \%$ arginine)

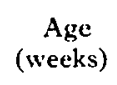

I

3

9

$\left.\begin{array}{ll} & \text { Diet } \\ A & B \\ 3100 & 2600 \\ 2350 & 2300 \\ 3600 & 3200 \\ 2800 & 3100\end{array}\right\}$

Standard error

$(25 \mathrm{df})$

$\pm 45^{\circ}$

Age and dietary arginine level. Forty day-old White Rock male chicks were weighed and five allocated at random to each of a block of eight wire cages. During the Ist week the temperature was set at $98^{\circ} \mathrm{F}$ and was reduced by $5^{\circ} \mathrm{F}$ each week until $68^{\circ} \mathrm{F}$ was reached. Lighting was controlled by a time switch and was continuous for $20 \mathrm{~h}$ a day. Two diets were prepared, one containing $\mathrm{I} \cdot 2 \%$ arginine and the other $0.8 \%$. They were identical with the basal diets $\mathrm{A} 6$ and $\mathrm{A} 9$ respectively, described by Lewis, Smith \& Payne ( 1963$)$. Each diet was given ad lib, to the birds in four cages. Water was also given ad lib.

Kidneys were removed from chicks at r, 3, 6 and 9 weeks of age and arginase activity was determined in the standard manner. One bird was taken from each cage at each age interval. The performance of the birds in terms of live-weight gain and efficiency of food utilization was similar to that reported by Lewis et al. (1963). The results of the arginase assays are presented in Table 2 . There is considerable variation within samples, but throughout the groups there was no indication that the activity varied in a manner that could be correlated with either age or dietary level of arginine. 


\section{DISCUSSION}

These results confirm that the enzyme arginase is located in both the liver and kidney of the domestic chicken, and a preliminary investigation has been made of its properties. The examination of the effect of $\mathrm{Mn}^{2+}$ ions upon the arginase activity of homogenates of chick kidney was pursued only so far as to allow the selection of appropriate conditions for assay. The results do, however, demonstrate that chick arginase is similar to the mammalian enzyme in that it is activated by $\mathrm{Mn}^{2+}$ ions and, moreover, that this activation occurs slowly (Greenberg, 195I). Though increase in concentration of $\mathrm{Mn}^{2+}$ ions encouraged activation up to a point, there was at high levels a decrease in activity whose cause has not been elucidated.

The demonstration of an optimum $\mathrm{pH}$ at around $\mathrm{r} O$ also agrees with the results obtained for the mammalian enzyme. The shape of the $\mathrm{pH}$-activity curve is also similar in that there was a particularly rapid decrease in activity at a $\mathrm{pH}$ more alkaline than the optimum.

The value obtained for the $K_{m}$ of arginase with arginine as substrate, $7.7 \times 10^{-3} \mathrm{M}$ at $\mathrm{pH} 9.5$, agrees well with that around $7 \times 10^{-3} \mathrm{M}$ reported by Bach \& Killip (1960) for mammalian hepatic arginase at the same $\mathrm{pH}$. The discrepancy between both these figures and that recorded for the mammalian enzyme at $\mathrm{pH}$ 10 by Schimke (1962), i.e. $2 \cdot 5 \times 10^{-3} \mathrm{M}$, is probably a result of the reduction of the substrate affinity of arginase as the $\mathrm{pH}$ moves away from the optimum.

The values obtained for the activity of arginase were considerably higher than comparable figures (Schimke, 1962; Cohen \& Brown, 1960) for the rat. The difference is probably due to the particular attention given in the method described here to the selection of favourable conditions for assay.

All the results confirm that the chick possesses an enzyme whose properties closely resemble those of mammalian arginase. In spite of the apparently purely destructive function of the enzyme in the chick, its activity in the kidney is higher than in the rat. There is also a definite activity in the liver of the chick. In neither organ does it appear to serve an essential function (ornithine can arise from transamidination) and it must therefore contribute to the relatively high requirement of the chick for dietary arginine. It is likely that only the arginine that escapes the action of the enzyme arginase is available for creatine and protein synthesis.

Though a prominent feature of the arginase activity of the chick is its large variability compared with that of the rat, and though there also appears to be considerable variability in the chick's dietary arginine requirement, it has not been possible to link the two factors. The variability in terms of arginase appears to be a characteristic of the individual bird, whereas that of requirement seems to be associated with amino acid balance in the diet (see Lewis et al. 1963). It has not been possible to demonstrate that kidney arginase activity is related to age or dietary arginine level. It is clearly desirable to examine activity in relation to species, strain, type and individual. 


\section{SUMMARY}

I. A procedure has been described for the assay of the arginase activity of chick kidney and liver homogenates.

2. The kinetic properties of the enzyme have been examined: the optimum $\mathrm{pH}$ is around 10, a $K_{m}$ value of $7 \cdot 7 \times 10^{-3} \mathrm{M}$ has been found, and the effects of cofactor concentration and pre-incubation have been examined in some detail.

3. There was a considerable arginase activity in preparations of chick kidney: there was a measurable activity in the liver but it was much less than that of rat liver.

4. It was not possible to demonstrate any difference in chick kidney arginase activity in relation to the age of the bird or arginine content of the diet.

We acknowledge the receipt of a grant from the Agricultural Research Council which made the work on arginine in poultry nutrition possible. One of us (G.H.S.) received a research scholarship from Genatosan Ltd, Loughborough, who also supported the work in other ways. We are particularly grateful to Miss P. M. Copestake for assistance in examining the effects of age and diet upon chick kidney arginase activity.

\section{REFERENCES}

Akashi, S. (1937). \%. Biochem., Tokyo, 26, 129.

Bach, S. J. \& Killip, J. D. (r 960). Biochem. F. 77, 7 P.

Baldwin, E. (1935). Biol. Rev. Ir, 247.

Chaudhuri, A. S. (1927-8). Brit. Y. exp. Biol. 5, 97.

Clementi, A. (1915). Arch. Fisiol, 13, 189.

Cohen, P. P. \& Brown, G. W. (1960). In Comparative Biochemistry. Vol. 2, p. 161. [M. Florkin and H. S. Mason, editors.] New York: Academic Press Inc.

Edlbacher, S. \& Rothler, H. (1925a). Z. physiol. Chem. 148, 264

Edlbacher, S. \& Rothler, H. (1925b). Z. physiol. Chem. 148, 273.

Greenberg, D. M. (195 r). The Enzymes. Vol. 1, Part 2, p. 893. [J. B. Sumner and K. Myrbäck, editors.]

New York: Academic Press Inc.

Gross, E. (1920). Z. physiol. Chem. 112, 236.

Klose A. A., Stokstad, E. L. R. \& Almquist, H. J. (1938). F. bial. Chem. 123, 69r.

Lewis, D., Smith, G. H. \& Payne, C. G. (1963). Brit. Y. Nutr. 17, 415.

Lineweaver, H. \& Burk, D. (1934). F. Amer. chem. Soc. 56, 658.

Potter, V. R. \& Elvehjem, C. A. (1936). Y. biol. Chem. r14, 495.

Schimke, R. T. (1962). F. biol. Chem. 237, 459.

Van Slyke, C. D. \& Archibald, R. M. (1946). F. biol. Chem. 165, 293. 